\title{
Promissory Infrastructures for Environmental Politics
}

\section{The Power of Digitalisation and its Stabilisation of Capitalist and (Un)Sustainable Developments}

Ingmar Lippert

[1] Technologies in Practice Research Group, IT University of Copenhagen; [2] Humanities of Nature, Leibniz Institute for Evolution and Biodiversity Science; [3] Chair of Technoscience Studies, Brandenburg University of Technology. Email: lippert@ems-research.org

\begin{abstract}
Supposedly, digitalisation offers new capacities and directions for environmental politics and governance. This chapter critically introduces the discursive trajectories of three 'developments', sustainable development, digitalisation and capitalist acceleration. Analytically, the chapter frames these trajectories with sensibilities developed in the sociology of promises, environmental sociology and science and technology studies. To illustrate how subjects and environments are differently (con)figured at the intersection of these trajectories, the chapter attends to two exemplary contexts and asks for each how subjects and environments are (con)figured. I address the contexts of global discourses and local dispositifs of smart cities and of carbon accounting/datafication. The chapter concludes in terms of digitalisation as promissory infrastructural relations that cut across these contexts. This raises avenues for critical environmental politics studies that are sensitive to discourses and dispositifs of greening in relation to recent innovations in analytics that recognise both epistemic/epistemological and ontic/ontological politics. With such attention, interesting problematisations and questions about transformative and conservative potentials emerge.
\end{abstract}

\section{Introduction}

Consider the power of critiques that are coupled with discursively privileged promises. Think of the promises of sustainable development, of data-driven governance of human-nature relations, of restructuring capitalist development to secure optimal techno-economic solutions. Such promises are powerful, this chapter outlines, in how they define the problems, which the promises promise to solve. Beyond their discursive effects, I argue that these promises also configure material infrastructures, shaping society, economy and the environment. The digital sits centre-stage, it stabilises key promissory developments in environmental politics and affirms itself.

In terms of promissory developments, I consider three. First, sustainable development is a discourse that turned hegemonic in the 1990s. It promises a political frame in which social, economic and environmental interests of current and future generations are negotiated and best policies developed. This discourse binds civil society, corporations and governments. Second, the use of information and data to power governance of human-nature relations can be identified across cases of empire-building and imperialism, much preceding current discourses of evidence-based decision-making. Contemporary governance promises to optimise control by establishing infrastructures for information gathering and processing. Yet, that control is systematically partial. Third, the restructuring of capitalist development is an ongoing process, reacting to economic, social and political crises. Promising to take on the modern horizon of crises (climatic, ecological, fiscal), capitalist accelerationisms address the political left and right, proposing techno-capitalist progress toward realising utopian futures.

I argue that these promissory developments play out not only discursively but also infrastructurally: digitalisation effects a promissory power that infrastructures environmental politics. It is infrastructural in terms of involving materiality, human and non-human agencies and relations (Bowker 2005). It is promissory in terms of imagining a

This is a preprint. 
future in order to enact a present to develop that future (Rajan 2006). To make this argument I mobilise sensibilities developed in Science and Technology Studies (STS): STS' ontological turn (here Verran 2001; Annemarie Mol 2002) allows recognising the political consequences of material and bodily practices that may, in situated practice, neither cohere with what practitioners claim nor with formal ontologies. A bridge can be built in many ways, and neither the architect's formal plan nor the master engineers can perfectly determine how each brick is set. Recognising epistemic and ontological politics powers analysing specific dispositifs that stabilise these promissory discourses. I illustrate difference and similarity of patterns of how discourses and dispositifs locate subjects and environments using two contexts that matter environmentally, politically and economically:

- smart cities - which are economically valued at around 1 trillion USD (Sadowski and Bendor $2019,545)$ and

- carbon accounting - which comes as part of carbon pricing instruments, capturing $20 \%$ of

GHG emissions and raising 44 billion USD in 2018 (World Bank 2019, 12).

A corollary of my argument for an infrastructural critique of promissory discourses in environmental politics and governance is to question an analysis of greenwashing as merely symbolic. Contexts like smart cities or carbon accounting and pricing are better not analytically 'reduced' to linguistic phenomena; instead, I propose analysing these contexts for how in their dispositifs material entities - including digital infrastructure as well as natural and environmental entities - are reconfigured, that is repositioned or relocated to effect specific political, organisational or economic realities.

This chapter proceeds in four steps. Section 1 portrays the analytical resources, drawn from STS. Presenting results of analyses in environmental sociology, anthropology and human geography, Section 2 lays out the three promissory developments and critics of these; and Section 3 presents analyses of the two empirical contexts of smart cities and carbon accounting. Section 4 concludes the chapter in terms of infrastructural entanglements.

\section{Turning promises into questions of infrastructural reconfiguration}

The sociology of technological expectations offers resources for studying the content of the futures set out in promises and of the actor constellations in 'selling' such expectations (Quet 2014, 211-13). The strength of this literature is studying specific technoscientific research agendas in the service of policy problems. I am interested specifically in the making and stabilisation of the discursive and material frames in which policy problems and solutions conduct their social and political life.

Broadly, this kind of interest can be considered post-structuralist. I address the relational constitution of how subjects and environments are imagined and positioned. The interdisciplinary field of STS has developed key analytical resources for empirically studying in the here \& now as well as the historicity of socio-technonatural relations. Bowker (2005) indicates that managing and governing environments has a history of using informational techniques to know natures. These techniques are not mere questions of epistemology but involve material shaping and form. Natures become entangled in, and accounted for, as environments. This allows to govern human subjects not only directly via human powers but also indirectly via the shaping of environments. Then, with Gabrys (2016b) a focus on environmentality - research into how environments are materially-informationally-naturally configured to shape social, political and economic life - becomes apt. Configuration emerges as a key concept that holds together these sensibilities. In configuration we find the figure, a character or a number, to play their part in a certain storyline that may be materially and semiotically enacted. For the storyline to work, figures are put in relation to each other, they emerge together (this togetherness is designated with the prefix 'con'). Suchman (2012) shows how these configurations are highly political, in their genesis, genealogy and what they generate. Yet, figures are not necessarily thoroughly captured by ontologies; indeed, some stories are played out in routinised practices that are never explicated or theorised - which STS accounts for as ontics (Verran 2009; Raasch and Lippert 2020). Ontics are part of stabilising and destabilising dispositifs. I use this STS literature to study how promissory discourses socio-materially configure or prefigure social, environmental, political and economic effects. 


\section{Promissory Developments?}

This section sketches the discursive trajectories of three contemporary 'developments' and critiques of these - sustainable development, digitalisation, and capitalist acceleration. Digitalisation provides a promissory power on which the other two developments feed.

Sustainable development is widely referenced back to the 'Brundtland report', authored by the World Commission on Environment and Development (1987). Typically foregrounded in such a reference is the norm of intergenerational, primarily ecological, justice. Another key reference is von Carlowitz's (1713) call for scientific forestry, that is sustaining the yield for timber production, promising to optimise ecology for economy. The 1990s innovation was to link this economic-ecological rationality to concerns of social justice and equality (Redclift 2005). This innovation promises a development to be sustainable, if the development considers social, economic and ecological criteria. Drawing in voices from the global south and north, sustainable development was established as hegemonic discourse at and in the aftermath of the 1992 United Nations Earth Summit. The discourse analysis of sustainable development by Dingler (2003) identifies four key promissory moves. (a) Production is supposed to be de-coupled from resource consumption; this implied that the limits of growth could be grown; for optimising resource use and dump (pollution) in the market, resources need to be internalised, informationally via accounting and economically via taxes or trade instruments. (b) Technological innovation would deliver on all these material expectations. (c) Global environmental management would identify and act, via policy advice, on ecological problems if the economy was not swiftly enough achieving greening. (d) In parallel, these processes and changes would be transparently accompanied by letting publics participate. The Earth Summit's 'Agenda 21' proclaimed participation at all levels and ecological modernisation implied NGOs would be invited into policy making.

Ecological modernisation ties in with, and strengthens, this discourse. Ecological modernisation policy, first conceptually prepared by thinkers like Huber (1988), pushes for a neoliberal reaction to global and local environmental crises. Environmental problems were framed as market problems, thus environmental troubles emerge as costs. Hajer (1995) identified fittingly, first, a shift away from judicial administration towards de-regulation - allowing the environment to be managed by the market. Second, the costs of environmental protection were reimagined as 'pollution prevention pays', rationalising the internalisation of all resources and pollution. Third, polluters were pushed to take on the burden of proofing they internalised and managed the environment well, whilst environmental NGOs were increasingly included in environmental governance. Relevant for environmental social sciences, ecological modernisation theory argues that indeed ecological modernisation delivers - that environmental concerns became central to, at least, Western societies, and effect gradually the greening of economies (Arthur P.J. Mol 2001; Huber 2008; Jänicke 2017).

The hegemonic discourse of sustainable development is accompanied by a range of voices and critics. Some point to a long history of a caring relationship between people and their lands (e.g. Washington 2015). Others point out the managerialist drive towards an 'ecocracy' (Escobar 1995, 193), the sidelining of the critique of modernisation theories and not allowing more economic justice globally (Eblinghaus and Stickler 1996). Blühdorn (2007) analyses sustainable development as sustaining the unsustainable.

Digitalisation is a process in which life worlds and their entities are, supposedly, ever more datafied, i.e. recorded and maintained in data sets. This promises some of the players and users in these worlds improved management and control, a systematic accounting and oversight of that world. The notion of digitalisation easily evokes the imaginary of radical change, an informational revolution, challenging the human understanding of our own and our world's existence (Floridi 2009). In principle, the discourse of digitalisation promises that everything can be datafied, thus better controlled. Supposedly, the promises merely depend on technical progress.

This discourse meets several political and analytical critiques. First, if a life world gets widely digitalised and thus rendered subject to control, the controlling actors will use the data to govern, and the politics of that may well be hidden behind a technocractic veil. Second, the very assumption that something can be fully digitalised is normally not realistic; pretending it ignores the entities or qualities that do not fit into the patterns of programming and databasing. Recognising that programming requires choices of how to conceptualise the entities that are recorded (and to be managed) makes evident that digitalisation involves decision-making that 
cannot be neutral and can never be conducted outside of societal influence. With Verran, we can call this ontological politics. Finally, running hardware and software requires energy and resources, human and natural. Digitalisation is unavoidably bound to environmental, social and economic exploitation. These critiques are not innovative - instead they indicate that to a significant degree, digitalisation's imagined radical newness may not be the case. Informational politics - decisions about who records something, how something is recorded, how the recording is processed and used - have decades and centuries of history (Bowker 2014).

Capitalist acceleration has been evoked as a strategy towards a better world both by the political left and the right. One evocation, 'An Ecomodernist Manifesto', emerging in the context of The Breakthrough Institute, promises a 'great Anthropocene' (Asafu-Adjaye et al. 2015, 31). The other, the 'Manifesto for an Accelerationist Politics', emerging in the left reaction to Nick Land's (right-accelerationist) thought, promises a post-capitalist future (Williams and Srnicek 2013). The ecomodernist manifesto rejects notions of harmony between humans and nature, instead calling for, e.g., the intensification of agriculture, nuclear energy and geo-engineering. The other manifesto is more utopian, arguing to propel technological progress and experimentation (like the 1970's Chilenian Cybersyn project) to exceed existing capitalist forms. On the way, this post-Marxist proposal suggests, the current capitalist and neoliberal infrastructure should be the base on which to build towards post-capitalism, ultimately accelerating our technological race into outer space.

The overarching line of critique against both versions of accelerationisms problematises their technological determinism. Both are committed strongly to the use and acceleration of technological development, aka progress and innovation, to ensure abundant energy, food, prosperity (and for the leftist version, also increasing freedom). Whilst both accelerationisms problematise specific forms of old technologies or of the governance of technologies, both manifestos uncritically presume their preferred technological development to deliver on their intended uses. This technological naivety does not consider the politics necessarily written into hardware, middleware and software. Environmentally, Pellizzoni (2019) identifies in both manifestos a disregard for the rebound effect, i.e. that technological efficiency gains can be expected to lead to more absolute resource use. The Ecomodernist Manifesto operates with a redefined concept of nature that allows the authors to make the claim that renewable energy production leaves less room for nature than nuclear power (Asafu-Adjaye et al. 2015, 18). Williams and Srnicek's (2013, § 22) Manifesto, similarly, suggests that the alternative to their techno-utopian approach leads via primitivism to ecological collapse.

Despite their differences, these three developments share that they promise mastery of nature and of aligning that mastery with social and economic satisfaction. Digitalisation provides the promissory and material infrastructure for conjuring up the imagined feasibility of this success story.

Over the last two decades sustainable development was deeply recast by the promissory discourse of digitalisation and numerical indicator/target oriented reporting (see also Arthur P.J. Mol 2008). The 1992's UNled Agenda 21 process was appreciated in expert discourse as leading to globally distributed take-up of sustainability ideas in local governance structures. Agenda 21 also called for sustainability monitoring and reporting. However, the same process was weak in ensuring such reporting. In reaction to this weakness, the UN first centrally introduced the Millennium Development Goals, 'proving' that global indicator-driven reporting was possible. The current Sustainable Development Goals (SDGs) demand more of nation states in terms of (re)datafying all kinds of sustainability dimensions (differentiated by 232 indicators).

Persson et al. $(2016,67)$ expect the 'data revolution' to innovate monitoring of current indicators. However, unsurprisingly, such a digitalised approach to monitoring sustainable development is characterised by conflict and debate about the choice and design of indicators (Hák et al. 2016; Spangenberg 2016). Despite the radical talk of revolution - Arthur P.J. Mol (2008) refers to the accelerating information revolution - technological 'progress' in environmental data configuration does not resolve conflict, but propels contestation and ambiguities. Environmental data gets only more complicated and problematic when it gets interwoven with the assemblages of the Internet of Things (IOT), Big Data analytics and remote, e.g. satellite driven, monitoring/sensing. Gabrys (2016a), Lippert (2016a) and Nadim (2016) show how these promissory assemblages put at risk both democratisation and economies. 


\section{Problematising the relation between digitalisation and the environment}

Above, this chapter has sketched resources for analysing infrastructural, ontological and epistemic politics and configurations, drawing on STS. Thus informed, considering sustainable development, digitalisation and capitalist accelerationisms suggests that material practices at the intersection of these promissory developments raise significant critical concerns. To ground this suggestion, I analyse smart cities and carbon accounting. Specifically, this sections illustrates how subjects and environments are differently (con)figured in these exemplary critical contexts.

\subsection{Smart cities}

The notion and discourse of smart cities emerges in the context of urban infrastructural experimentation for sustainability transitions (Bulkeley and Castán Broto 2013). Whilst the notion of smart cities became widespread in the early 2000s, the reimagination of cities' informational configuration includes older phenomena, like the introduction of cable television into cities or cybernetic control hopes (Viitanen and Kingston 2014, 805). Whilst smart cities can be discursively differentiated from eco-cities, both discourses privilege economic growth and technological progress as powering the envisaged sustainable future (Cugurullo 2017, 74), such as a climate resilient city (Allen and Deal 2018).

Social scientific analyses of smart cities point to three sets of transnational actors as shaping specific urban experiments (Viitanen and Kingston 2014, 803; Sadowski and Bendor 2019). For experimenting, (a) transnational corporations like IBM and Cisco collaborate with the specific city's authorities, firms and researchers. (b) Transnational corporations and (c) intergovernmental organisations (e.g. World Bank, OECD, EU) are decisive in shaping the discourse and defining what counts as smart (Leitheiser and Follmann 2020). Translocal rather than transnational organisations, for instance city networks (C40 Cities, Covenant of Mayors etc.), are accorded attention in literature on policy mobility, networked governance and polycentric governance (Heijden 2018).

In these actor arrangements, smart cities are proposed as viable solutions to grand problems, within the framing of sustainability, typically including rapid urbanisation, fiscal austerity, climatic catastrophe (Sadowski and Bendor 2019, 549) and squaring solutions for these problems with economic growth (Viitanen and Kingston 2014). However, maybe not unsurprisingly for such a promissory discourse, smart cities are also found to promise justice - both environmental (Gabrys 2016b, 202) and social justice (Trencher and Karvonen 2017). Imagined as an automatic consequence, the users of a smart grid in a city are figured as smart citizens (Levenda 2019, 573). The technological narrative mobilised to promise fitting solutions claims that data from everywhere will allow precise data gathering, modelling and, thus, governance, allowing for deeply-informed sustainability (Kitchin 2013). ${ }^{1}$ In short, the smart city is a promise for an eco-city.

Whilst the promissory language of smart cities superficially signals a master plan and singular implementation, discourse analysis identifies several types of imaginaries of implementation (Sadowski and Bendor 2019, 554-5). On the ground, different actors in smart developments have different visions of users and of technologies (Schick and Winthereik 2013). Smart city implementations do not actually operate topdown but involve contestation and negotiation (Cugurullo 2017, 74). Recognising that the smart city promise does not deterministically imply a singular implementation provides sensibility to ask how smart city discourses are patterned. Sadowski and Bendor (2019) show the typical narrative as structured by four figures: first, the city faces multiple crises; second, the city is in need of transformation; third smartness is the solution; fourth, that smartness needs implementation. The multinational companies involved offer themselves as guides and collaborators in cities' process to get smart. Specifically, these corporations promise to remove the uncertainties of the process and of the risks of people and environments, such as of the unpredictable climate (Viitanen and Kingston 2014, 805; Sadowski and Bendor 2019, 549-50).

The technical solution envisaged is framed by Cisco as connecting people, data/information and things, by IBM in terms of sensors, monitoring and analyses (Sadowski and Bendor 2019, 551-52). The data empowering these connections are supposed to be big (big data!) and available in real time (Kitchin 2013). In

${ }^{1}$ A related, but not as prevalent, discourse understands a smart city as a region in which smart innovative knowledge is developed, enabled by information and communication technologies (Kitchin 2013). 
the logic of big data, these mantras results: data can never be enough - the more the data, the better the government.

Critical scholars focus very much on how a range of urban environmental policy imperatives gets translated in the dominant discourse into individual responsibilities to act differently and to track that difference with data (Levenda 2019). This raises the question of who defines and constructs data, who includes or excludes data from data gathering and analysis (Kitchin 2013, 8-9). Social scientists have problematised the democratic control over these practices. Viitanen and Kingston (2014, 814), Leitheiser and Follmann (2020) and Sareen and Rommetveit (2019) suggest that in smart city and grid arrangements, citizens are more likely to take on the role of figures that are informed rather than of figures that are involved in handling and control over energy/data; corporations and algorithms are figures that are attributed more agency to shape the city, and individual users lose choice and freedom (Levenda 2019, 574). Aligned with such a critique is the social scientific recognition of resistance against smart cities on the ground (Leitheiser and Follmann 2020). The smart city meets the non-smart; alternative imaginaries thrive - considering the informational politics of urban governance drawing on urban social justice, urban commons and civic hacking (Sadowski and Bendor 2019, 544; North and Nurse 2014).

STS analyses draw out how smart city dispositifs are not necessarily strictly organised in a binary struggle between citizens and hegemonic actors. Instead, studies of socio-technical assembling nuance the political critique by pointing out that within expert discourses, a range of alternative subject positions are considered and contested (Schick and Winthereik 2013). Not only does the smart city engage citizens, but also consumers, technocrats, managers, engineers; and actual people typically occupy complicated subject positions, not just being, for instance, a worker or a capitalist but also a parent, citizen, activist. According to Gabrys, citizenship is transformed into citizen sensing; the citizen is turned into 'a data point, both a generator of data and a responsive node in a system of feedback' (Gabrys 2016b, 196). In consequence, the mode of political participation is redefined in terms of data: the citizen senses her city, lets the smart city conduct analyses and decisions, and subsequently the citizen is acted upon (199-200). However, the dispositif is still allowing for complexity: a user can act outside of what algorithms expect, intentionallysubversively or unintentionally. Cities, the state and corporations do not appear as a monolithic front, but as a heterogeneous urban assemblage, in which players like Facebook or Google may be much more easily publicly rendered accountable compared to the range of start-ups and other short-living firms involved, little known and controlled, but providing 'smart' services for the other players. It is expertise of data and software that matters, rather than of specific or situated knowledge of urban context and specific complexities (Söderström et al. 2014). No wonder, then, that in a smart city implementation we may find an environmental public authority excluded from the role of key actors (Cugurullo 2017, 85).

Beyond analyses of the partial control over users and data, smart cities also reconfigure urban-environment relations. As not every square meter can be equally well datafied, the practical politics of where sensors are placed is acted out; what does remote sensing focus on (Parikka 2017)? Using specific corporation's technologies in reconfiguring the city, means that the access and relation to the environment itself becomes subjected to issues of vendor lock-in (if we assume effective control of the smart technologies) or of a buggy and hackable city (considering the impossibility of complete control of and by smart technologies) (Kitchin 2013). Beyond configuring the environment via data, the smart city is intensively characterised by new hardware and maintenance needs and intensive software upgrades (requiring ever more resource-hungry devices). Gabrys (2016b, 198) observes that the corresponding environmental impacts are not subject to smart city deliberation and seem implicitly assumed to be 'smartly' conjured away. This ignores how the smart city, and its more or less complicit inhabitants, socio-materially configure an increased consumption of energy and hardware (Viitanen and Kingston 2014).

The discourse of smart cities discursively and materially stabilises a set of interrelated promises. Presumably, smart cities are ecocities; and smart cities perform stakeholder participation, orchestrating encounters between (some) citizens, corporate players and governments. In that respect, smart cities form a frictionless part of the hegemonic discourse of sustainable development. That smart cities thrive on the promises of digitalisation is most obvious: the smart city is digital, and the more digital, the more data, the better, the more sustainable it claims to be. The smart city provides a material space of experimentation for capitalist 
transformation. Corporations are not merely part of global governance (Google, Facebook), but also of local sustainability transformation. In the smart city, companies find a framework to perform promises of innovation. Typically backgrounded within the entangled promises are the epistemic and material politics of smart cities: their new infra-structures are strongly shaped by the distribution of what is considered relevant knowledge about data/natures; as infrastructure, such epistemic politics gets materialised, written in bits, bytes and bricks.

\subsection{Datafying Corporate Carbon Emissions}

The hegemonic climate governance discourse employs a model of greenhouse gases (GHG) that privileges attention to universal gas concentration: the global average amount of carbon dioxide in the atmosphere and other GHG drives global warming. In this model it does not matter where these gases are emitted. That the gases are emitted is understood as a market failure - emissions are framed as externalisation of costs (Stern 2006). The solution then is to 'internalise' the emissions via market systems (trade or taxes: cf. Lohmann 2009). In the logic of ecological modernisation, emitters know best what they emit. Therefore the organisations that emit are to account about their emissions themselves. In the following, I primarily consider how corporate emissions are accounted for under least-regulated market conditions. How do organisations account for themselves? They do so within an interorganisational network. This typically encompasses a range of organisations: the emitter; a standardisation organisation that defines what counts as emissions and how emissions are to be counted; an auditor that scrutinises the emitter's practices for whether the chosen standards are met; and organisations that control the social and public license to operate and continue emitting, a category which includes non-governmental organisations in partnership with companies and public authorities that refrain from conducting monitoring themselves. In these interorganisational relations a lock-in can be observed that stabilises the network, tying the organisations together, preventing critique and avoiding troubling questions about how emissions are actually reported (Lippert 2016b).

Beyond the politics that can be identified in this network, such as in the standardising organisations (Lovell and MacKenzie 2011) and in the technical devices for measuring emissions (MacKenzie 2009; Liu 2017), the very work of datafying carbon, of constructing a carbon footprint, within the emitting organisation has emerged as a site of political choices and normative assumptions. Vesty et al. (2015) identify how carbon numbers do not simply quantify emissions but are also used to value responsibility of actors within organisations or to normatively compare organisations. Lippert (2015) shows how carbon data is enacted involving internal contestation and conflict. And that data is imagined to be 'sourced' from sites of emissions, which themselves do not allow straightforward simple measurement, but rather raise significant uncertainties and ignorance (Liu 2017; Lippert 2018).

In a context in which the various involved actors within an organisation know, more or less, about carbon datafication choices, politics and uncertainties, that very political and interpretative flexibility serves both as a chance and as a thread. One corporate reaction to this situation is to find ways of performing carbon that simultaneously satisfy competing demands and interpretations. For instance, the difference of paradigms for calculating a data point (resulting in different versions of that data point, different numerical values) can be rendered invisible by reproducing the genre of precise data (10.27 gigatonnes and 10.34 gigatonnes can both be rounded up/down to 10.3 gigatonnes). Beyond changing the data (presentation), it is also possible to change the data interpreters. Lippert (2013, Ch. 4.4) shows how a company has removed all the environmental engineers and facility managers from the data collection process, substituting these with financial bookkeepers who were expected by the company to not know well the physical matters relevant for carbon calculations (such as kilowatt hours for electricity consumption calculations). Substituting groups of workers can, then, deliver a process of carbon accounting that produces a footprint more smoothly, at the cost of ignoring uncertainties and conflicts of interest.

Once a carbon footprint is established, the organisation can 'outsource' the emissions it has calculated as having emitted (Ninan 2011): it can buy negative emissions via the carbon market and add these to its footprint, calculatively reducing its footprint by e.g. $20 \%$, even by $100 \%$ to be carbon 'neutral' or by even more to be carbon 'negative'. Fitting to the possibilities of such arithmetic exercises and to financialised carbon is the risk of a crisis of carbon finance, implying the risk of misjudging emissions at a global scale: 
subprime carbon (Chan 2009). In the historically new voluntary carbon market, innovation can lead to effects like defining negative (avoided) emissions as being produced not only by planting trees or substituting a coalfired power station by a wind power, but also by investing in a renewable energy project (as if the process of investing, the financial transaction, avoids emissions: cf. Lippert 2017). The market decides what counts as emission reduction.

Datafying carbon reconfigures the organisation. Literally, carbon figures, i.e. numbers, may be inscribed into manifold internal corporate processes. For ecological modernisation theory, this supposedly confirms their diagnosis of environments figuring more centrally in organisations. Specifically, a range of workers are demanded to consider, and communicate in terms of carbon, thus changing accountability relations. Also, some actors are typically assigned authority over carbon, reconfiguring their position in the organisation. Carbon figures also in external communication. By communicating carbon emission, the organisation showcases to its public audiences that it is a skilled member of an environmentally concerned society (Lippert 2011).

Carbon gets configured in most of these practices as data (Lippert 2015). This means that carbon is not handled directly as molecules but rather as information that indexes emissions. This matters insofar as carbon as data can be reduced differently compared to actually handling emissions. Carbon-as-data can be reduced on paper, in a spreadsheet or in another database. Another form in which carbon is practiced is aesthetically: carbon becomes both a symbol of sustainability (Vesty et al. 2015) and part of symbols of greening, such as trees, wind power, lakes, mountains (Lippert 2013, Ch. 3.5).

Datafying corporate carbon emissions effectively stabilises a set of promises. In terms of ecological modernisation, accounting for carbon emissions signifies environmental accountability, evoking the idea that companies partner in striving for sustainable development, alongside governments, science and NGOs. Using the language of carbon, or $\mathrm{CO} 2$, is also interpreted as a generic form of taking on greening and environmental sustainability. Digitalisation performs at least two significant promises in this context. On the one hand, a database of emissions serves to back up the discourse of evidence-based decision-making. On the other hand, turning environmental entities into informational entities allows to reconfigure this environment-asdata for instance by way of employing different algorithms and data formats. Carbon as a thoroughly informationalised entity becomes a referenceable object for economic transactions. Discourses of market, cap and trade or tax solutions thence gloss over the unruly realities of material-molecular-industrial carbon relations on the ground. This set of promises is undermined by the frictions of knowing carbon. The datafication process necessarily ignores uncertainties and is not even able to grasp factors and problems on the ground that do not get documented in the first place.

\section{Recognising infrastructural entanglements}

Critical environmental policy studies are faced with powerful promissory discourses and transformations. This chapter considered sustainable development, digitalisation and capitalist accelerationisms. Using two empirical contexts, smart cities and corporate carbon accounting, I showed that these promissory developments can also be entangled. These discourses can be analysed as mutually sustaining themselves. Infrastructurally, too, shared in both contexts are digital and environmental promises and premises. These premises do not merely matter discursively, but also materially. The promises themselves are entangled in infrastructures and are components in (infra)structuring the discourses of sustainable development, digitalisation and capitalist accelerationisms. These discourses form a promissory infrastructure.

Promissory discursive developments key to environmental politics are bound together by the imaginary of data. And data figures centrally in both contexts: data is the form in which the environment gets significantly known, understood and processed. In that respect, environmental data is shaped by an epistemic politics: who knows environments how, whose knowledge gets in- and excluded? However, environment as data is not disembodied. Environmental data comes in brains who are in- and excluded from meetings; data comes in databases that is materially based in hardware, which may fail; data is produced using sensors and algorithms that materially translate, and thus shift, what environment comes to be in and as data. The environment appears as a datascape (Lippert 2015). This kind of analysis recognises that actors do not merely engage in epistemic politics but also in material politics that shape how environments are materially done, as 
data, and materially translated. Environmental politics is thus played out in bits, bytes and bricks. Analysing this 'play' as ontological politics foregrounds how both contexts are shaped by formal ontologies and material practices of control: not all data matters equally, only some data is generated and processed for decisionmaking, other realities are silenced, or simply not given voice.

Yet, not all is under control in environmental datascapes. Whilst ontologies about environmental entities may be written into code, that writing process is as much prone to error, to ignorance and unknown unknowns, as are the practices of mapping environmental entities 'out there' onto a signifier in the database. In both empirical contexts I find human actors who take part in shaping environmental politics on the ground, shaping environmental infrastructures, but who do not and cannot completely identify all the ways in which their work practices shape environmental-data realities. Practices that shape reality but which are not completely (maybe not even much) theorised, thought through, can be meaningfully designated not as ontological practice but as ontic (Verran 2009; Lippert 2018). With infrastructure studies I recognise how in smart cities and carbon accounting infrastructures are built not completely anew, from fresh, but always on an historically constructed 'base'. The visionary futures of the promissory discourses then, not necessarily consciously, also have a reactionary effect as the existing material and political base is stabilised. Working critically and materially towards heterotopias needs to consider how any infrastructural work affirms and entangles the dynamics of material and power, which any promissory project or movement is based upon.

\section{References}

Allen, James, and Brian Deal. 'Military Climate Resilience Planning and Contemporary Systems Thinking.' Projections (2018). doi:10/fcw2

Asafu-Adjaye, John, L Blomqvist, S Brand, B Brook, R Defries and E Ellis. 2015. An ecomodernist manifesto. Accessed 14 February 2020.

https://web.archive.org/web/20200214084406/https://static1.squarespace.com/static/ $5515 d 9 f 9 e 4 b 04 d 5 c 3198 b 7 b b / t /$ 552d37bbe4b07a7dd69fcdbb/1429026747046/An+Ecomodernist+Manifesto.pdf.

Blühdorn, Ingolfur. 2007. 'Sustaining the unsustainable: Symbolic politics and the politics of simulation'. Environmental Politics 16, no. 2: 251-75. doi:10/bfn8p5.

Bowker, Geoffrey C. 2005. Memory practices in the sciences. London and Cambridge, Massachusetts: MIT Press.

Bowker, Geoffrey. 2014. 'All together now: Synchronization, Speed, and the Failure of Narrativity'. History and Theory 53 (4): 563-76. doi:10/bjbx.

Bulkeley, Harriet, and Vanesa Castán Broto. 2013. 'Government by experiment? Global cities and the governing of climate change'. Transactions of the institute of British geographers 38 (3): 361-75. doi:10/f42f29.

Chan, Michelle. 2009. Subprime Carbon? Re-thinking the world's largest new derivatives market. Technical report. Washington: Friends of the Earth.

Cugurullo, Federico. 2017. 'Exposing smart cities and eco-cities: Frankenstein urbanism and the sustainability challenges of the experimental city'. Environment and Planning A: Economy and Space 50, no. 1: 73-92. doi:10/gc26v4.

Dingler, Johannes. 2003. Postmoderne und Nachhaltigkeit: Eine diskurstheoretische Analyse der sozialen Konstruktion von nachhaltiger Entwicklung. Vol. 7. Hochschulschriften zur Nachhaltigkeit. München: ökom.

Eblinghaus, Helga, and Armin Stickler. 1996. Nachhaltigkeit und Macht: Zur Kritik von Sustainable Development. Mithrsg.: Informationsbüro Nicaragua e.V. Frankfurt/Main: IKO - Verlag für Interkulturelle Kommunikation.

Escobar, Arturo. 1995. Encountering Development: The Making and Unmaking of the Third World. Princeton University Press.

Floridi, Luciano. 2009. 'The Information Society and Its Philosophy: Introduction to the Special Issue on "The Philosophy of Information, Its Nature, and Future Developments" '. The Information Society 25, no. 3: 
153-58. doi:10/frnj7r.

Gabrys, Jennifer. 2016a. 'Practicing, materialising and contesting environmental data'. Big Data \& Society 3 (2). doi:10/gcdx9z.

Gabrys, Jennifer. 2016b. Program Earth: Environmental Sensing Technology and the Making of a Computational Planet. Minneapolis: University of Minnesota Press.

Hajer, Maarten A. 1995. The Politics of Environmental Discourse: Ecological Modernization and the Policy Process. Oxford: Clarendon Press.

Hák, Tomáš, Svatava Janoušková and Bedřich Moldan. 2016. 'Sustainable Development Goals: A need for relevant indicators'. Ecological Indicators 60: 565-73. doi:10/f75twt.

Heijden, Jeroen van der. 2018. 'City and Subnational Governance: High Ambitions, Innovative Instruments and Polycentric Collaborations?' Chap. 5 in Governing Climate Change: Polycentricity in Action?, ed. Andrew Jordan, Dave Huitema, Harro van Asselt and Johanna Forster, 81-96. Cambridge University Press.

Huber, Joseph. 1988. Die Regenbogen-Gesellschaft. Frankfurt am Main: Fischer-Taschenbuch-Verlag.

Huber, Joseph. 2008. 'Pioneer countries and the global diffusion of environmental innovations: Theses from the viewpoint of ecological modernisation theory'. Global Environmental Change 18, no. 3: 360-67.

Jänicke, Martin. 2017. 'Ecological Modernization as Global Industrial Revolution'. Journal of Environmental Policy and Administration 25, no. S: 1-32. doi:10/fnts.

Kitchin, Rob. 2013. 'The real-time city? Big data and smart urbanism'. GeoJournal 79, no. 1: 1-14. doi:10/7ds.

Leitheiser, Stephen, and Alexander Follmann. 2020. 'The social innovation-(re)politicisation nexus: Unlocking the political in actually existing smart city campaigns? The case of SmartCity Cologne, Germany'. Urban Studies: 57, no.4: 894-15. doi:10/fntt.

Levenda, Anthony M. 2019. 'Thinking critically about smart city experimentation: entrepreneurialism and responsibilization in urban living labs'. Local Environment 24, no. 7: 565-79. doi:10/gf4xq4.

Lippert, Ingmar. 2011. 'Extended Carbon Cognition as a Machine'. Computational Culture (1). Accessed 5 December 2011. http://computationalculture.net/article/extended-carbon-cognition.

Lippert, Ingmar. 2013. Enacting Environments: An Ethnography of the Digitalisation and Naturalisation of Emissions. PhD thesis, Augsburg University, Philosophisch-Sozialwissenschaftliche Fakultät. doi:10/6vh.

Lippert, Ingmar. 2015. 'Environment as Datascape: Enacting Emission Realities in Corporate Carbon Accounting'. Geoforum (66): 126-35. doi:10/wx8.

Lippert, Ingmar. 2016a. 'Failing the market, failing deliberative democracy: How scaling up corporate carbon reporting proliferates information asymmetries'. In 'Materialising, Practicing and Contesting Environmental Data', ed. Jennifer Gabrys and Nerea Calvillo, Big Data \& Society (July-December). doi:10/br76.

Lippert, Ingmar. 2016b. 'Umwelt - "Version 2b": Das Programmieren ökologischer Fehlentscheidungen und Grundlagen für eine neue Umweltpolitik'. Leviathan (44): 399-427. doi:10/bqpz.

Lippert, Ingmar. 2017. 'Corporate carbon footprinting as techno-political practice'. Chap. 6 in The Carbon Fix: Forest Carbon, Social Justice, and Environmental Governance, ed. Shirley Fiske and Stephanie Paladino, 107-18. New York, London: Routledge.

Lippert, Ingmar. 2018. 'On Not Muddling Lunches and Flights: Narrating a Number, Qualculation, and Ontologising Troubles'. Science \& Technology Studies 31 (4): 52-74. doi:10/cx2f.

Liu, John Chung-En. 2017. 'Pacifying uncooperative carbon: examining the materiality of the carbon market'. Economy and Society 46, nos. 3-4: 522-44. doi:10/fntv.

Lohmann, Larry. 2009. 'Toward a different debate in environmental accounting: The cases of carbon and costbenefit'. Accounting, Organizations and Society 34 (April-May): 499-534. doi:10/c7xgxm.

Lovell, Heather, and Donald MacKenzie. 2011. 'Accounting for Carbon: The Role of Accounting Professional Organisations in Governing Climate Change'. Antipode 43 (3): 704-30. doi:10/d2bxzj.

MacKenzie, Donald. 2009. 'Making things the same: Gases, emission rights and the politics of carbon markets'. Accounting, Organizations and Society 34 (April-May): 440-55. doi:10/cgvpmd. 
Mol, Annemarie. 2002. The Body Multiple: Ontology in Medical Practice. Durham, N. Ca., and London: Duke University Press.

Mol, Arthur P.J. 2001. Globalization and Environmental Reform: The Ecological Modernization of the Global Economy. Cambridge, Massachusetts: The MIT Press.

Mol, Arthur. 2008. Environmental Reform in the Information Age: The Contours of Informational Governance. Cambridge University Press.

Nadim, Tahani. 2016. 'Blind regards: Troubling data and their sentinels'. Big Data \& Society 3 (2): 1-6. doi:10/gcdx86.

Ninan, Anup Sam. 2011. 'Outsourcing Pollution: Clean Development Mechanism (CDM) as Ecological Modernisation'. Chap. 21 in Implementing Environmental and Resource Management, ed. Michael Schmidt, Vincent Onyango and Dmytro Palekhov, 263-82. Heidelberg: Springer. doi:10/d8r7zn.

North, Peter, and Alexander Nurse. 2014. 'Beyond entrepreneurial cities'. Métropoles, no. 15. doi:10/fntw.

Parikka, Jussi. 2017. 'FCJ-219 The Sensed Smog: Smart Ubiquitous Cities and the Sensorial Body'. The Fibreculture Journal, no. 29. doi:10/fntx.

Pellizzoni, Luigi. 2019. 'The environmental state between pre-emption and inoperosity'. Environmental Politics 29, no. 1: 76-95. doi:10/fntz.

Persson, Åsa, Nina Weitz and Måns Nilsson. 2016. 'Follow-up and Review of the Sustainable Development Goals: Alignment vs. Internalization'. Review of European, Comparative \& International Environmental Law 25, no. 1: 59-68. doi:10/ggcpb7.

Quet, Mathieu. 2014. 'It will be a disaster! How people protest against things which have not yet happened'. Public Understanding of Science 24, no. 2: 210-24. doi:10/fnt2.

Raasch, Josefine and Ingmar Lippert. 2020. 'Helen Verran'. In The SAGE Encyclopedia of Research Methods, ed. Paul A Atkinson, Sara Delamont, Melissa A. Hardy and Malcolm Williams. London: Sage. doi:10/fft6

Rajan, Kaushik Sunder. 2006. Biocapital: The Constitution of Postgenomic Life. Durham, NC: Duke University Press.

Redclift, Michael. 2005. 'Sustainable development (1987-2005): an oxymoron comes of age.' Sustainable Development 13.4: 212-227. doi:10/cjkr2q.

Sadowski, Jathan, and Roy Bendor. 2019. 'Selling Smartness: Corporate Narratives and the Smart City as a Sociotechnical Imaginary'. Science, Technology, \& Human Values 44, no. 3: 540-63. doi:10/gfdb9n.

Sareen, Siddharth, and Kjetil Rommetveit. 2019. 'Smart gridlock? Challenging hegemonic framings of mitigation solutions and scalability'. Environmental Research Letters 14, no. 7: 075004. doi:10/fnt3.

Schick, Lea, and Brit Ross Winthereik. 2013. 'Innovating Relations - or Why Smart Grid is not too Complex for the Public'. Science \& Technology Studies 26 (3): 82-102.

https://sciencetechnologystudies.journal.fi/article/view/55289

Söderström, Ola, Till Paasche and Francisco Klauser. 2014. 'Smart cities as corporate storytelling'. City 18, no. 3: 307-20. doi:10/gd57fs.

Spangenberg, Joachim H. 2016. 'Hot Air or Comprehensive Progress? A Critical Assessment of the SDGs'. Sustainable Development 25, no. 4: 311-21. doi:10/gbr3wp.

Stern, Nicholas Herbert. 2006. Stern Review: The economics of climate change. Vol. 30. London: HM treasury.

Suchman, Lucy. 2012. 'Configuration'. In Inventive Methods: The Happening of the Social, ed. Celia Lury and Nina Wakeford, 48-60. London, New York: Routledge.

Trencher, Gregory, and Andrew Karvonen. 2017. 'Stretching "smart": advancing health and well-being through the smart city agenda'. Local Environment 24, no. 7: 610-27. doi:10/gbvz2g.

Verran, Helen. 2001. Science and an African Logic. Chicago and London: University of Chicago Press.

Verran, Helen. 2009. 'Natural Resource Management's "Nature" and Its Politics'. Communication, Politics \& Culture 42 (1): 3-18.

Vesty, Gillian, Abby Telgenkamp and Philip Rosce. 2015. 'Creating Numbers: Carbon and Capital Investment'. 
Accounting, Auditing \& Accountability Journal 28 (3): 302-24. doi:10/2zx.

Viitanen, Jenni, and Richard Kingston. 2014. 'Smart cities and green growth: outsourcing democratic and environmental resilience to the global technology sector'. Environment and Planning A 46 (4): 803-19. doi:10/f6qwkk.

von Carlowitz, Hans Carl. 1713/2013. 'Sylvicultura oeconomica'. In The Future of Nature, ed. Libby Robin and Sverker Sörlin and Paul Warde, 67-74. New Haven: Yale University Press

Washington, Haydn. 2015. Demystifying Sustainability. Earthscan/Routledge, Taylor \& Francis.

Williams, Alex, and Nick Srnicek. 2013. '\#ACCELERATE: Manifesto for an Accelerationist Politics'. Accessed 14 February 2020. https://syntheticedifice.files.wordpress.com/2013/06/accelerate.pdf.

World Bank. 2019. State and Trends of Carbon Pricing 2019. Washington. doi:10/fnt5.

World Commission on Environment and Development. 1987. Our Common Future. Oxford: Oxford University Press. http://www.un-documents.net/wced-ocf.htm. 